\title{
ANALISIS PENGARUH FAKTOR INTERNAL PERUSAHAAN TERHADAP HARGA SAHAM PADA PERUSAHAAN MAKANAN DAN MINUMAN YANG TERDAFTAR DI BEI
}

\author{
AHMAD RIDHO FACHRIZAL CHAERY \\ Universitas Pamulang, Tangerang Selatan, Indonesia \\ *Email : ahmadridhofachrizalchaery@yahoo.co.id
}

\begin{abstract}
This research was conducted to test the influence of Internal Factors such as Liqudity, Activity, Solvability, Profitability and Company's Growth to the Stock Price. The object of this research is a manufacturing company of food and beverage sectors listed in Indonesia Stock Exchange in the period 2013 to 2017. This study uses multiple linear regression analysis that begins with the classical assumption, using a sample of 11 companie of food and beverage sector. The results obtained from this study is partially Solvability and Profitability has an influence on Stock Price, While Liquidity, Activity and Company's Growth do not affect significantly to Stock Price. Simultaneously the results obtained are all independent variables (Liqudity, Activity, Solvability, Profitability and Company's Growth) jointly have a significant effect on Stock Price.
\end{abstract}

Keywords : Liqudity, Activity, Solvability, Profitability, Company's Growth and Stock Price

\section{PENDAHULUAN}

\section{Latar Belakang}

Di era ekonomi modern seperti sekarang ini, perusahaan sangat membutuhkan tambahan modal untuk mendorong kinerja operasional perusahaan. Salah satu cara bagi perusahaan untuk mendapatkan tambahan modal adalah dengan menawarkan kepemilikan perusahaan tersebut kepada masyarakat / publik (go public).

Dalam pasar modal, tidak pastinya return yang akan diterima oleh seorang investor membuat seorang investor harus memilih dengan sangat hati - hati alternatif investasi yang harus dipilih. Dalam pasar modal, tidak semua saham dari perusahaan yang memiliki profil yang baik akan memberikan return yang baik pada investor, sehingga diperlukan analisis yang lebih mendalam mengenai

* Corresponding author's e-mail: ahmadridhofachrizalchaery@yahoo.co.id http://openjournal.unpam.ac.id/index.php/JIA 
Jurnal Ilmiah Akuntansi Universitas Pamulang - Vol. 7, No. 2, Juli 2019 - Marito \& Prasetya

perusahaan tersebut. Sebuah perusahaan mungkin saja mengalami return yang fluktuatif setiap saat karena berbagai macam faktor.

Perubahan harga saham dapat terjadi secara tak terduga karena harga saham di pasar modal dipengaruhi oleh tingkat permintaan dan penawaran terhadap saham yang beredar di pasar modal. Hal ini menyebabkan kegiatan di pasar modal Indonesia terus mengalami fluktuasi yang dapat tercermin secara umum melalui pergerakan harga saham pada masing-masing emiten. Harga saham merupakan cerminan dari kegiatan yang ada di pasar modal dan faktor yang mempengaruhi cerminan tersebut dapat berasal dari kondisi mikro maupun makro ekonomi. Indikator ekonomi mikro dan makro dapat dijadikan sebagai bahan pertimbangan untuk berinvestasi di pasar modal.

Rasio likuiditas digunakan untuk mengukur kemampuan perusahaan untuk memenuhi liabilitas jangka pendeknya. Salah satu rasio likuiditas yang paling umum dan sering digunakan adalah rasio lancar.

Rasio aktivitas juga disebut sebagai rasio efisiensi atau perputaran, mengukur seberapa efektif perusahaan menggunakan berbagai asetnya. Beberapa aspek dari analisis aktifitas sangatlah dekat hubungannya dengan analisis likuiditas. Dalam bagian ini, kita akan memfokuskan pada seberapa efektif perusahaan mengelola dua kelompok aset tertentu (piutang dan persediaan).

Untuk dapat menguji sejauh mana perusahaan menggunakan uang yang dipinjam dapat menggunakan rasio hutang (Leverage). Net Profit Margin is one kind of profitability ratio. This ratio show how cost effective the operational activities of a company. The Higher the ratio the better it is. Helfert (1997) dalam Hatta dan Dwiyanto (2012).

Tujuan yang diharapkan oleh investor pada saat ingin melakukan investasi pada saham, yaitu mengharapkan deviden dan capital gain dari saham tersebut, sehingga ada beberapa respon yang dilakukan oleh investor ketika menerima informasi mengenai pertumbuhan perusahaan. Perbedaan harga saham perusahaan yang tumbuh dan tidak tumbuh terbentuk atas suatu keyakinan bahwa keuntungan dan aliran kas di masa depan yang tumbuh lebih besar daripada perusahaan yang tidak tumbuh. Investor dan manajer perusahaan tertarik kepada pertumbuhan perusahaan karena memberikan aspek yang positif, pertumbuhan perusahaan merupakan signal atau tanda bahwa perusahaan memilliki prospek yang menguntungkan dan mereka berharap rate of return atas investasi mereka tanamkan akan lebih tinggi.

\section{Pembatasan Masalah}

Berdasarkan uraian di atas, faktor - faktor yang mempengaruhi harga saham sangat banyak. Dalam waktu yang sama, penulis memiliki keterbatasan waktu, biaya, tenaga dan kemampuan akademik. Menyadari kondisi tersebut, terutama sesuai dengan kaidah keilmuan, maka permasalahan penelitian ini penulis membatasi hanya pada masalah :

1. Rasio Likuiditas, Rasio Aktifitas, Rasio Solvabilitas, Rasio Profitabilitas dan Pertumbuhan Perusahaan

* Corresponding author's e-mail: ekhatyo11@gmail.com

http://openjournal.unpam.ac.id/index.php/JIA 
Jurnal Ilmiah Akuntansi Universitas Pamulang - Vol. 7, No. 2, Juli 2019 - Marito \& Prasetya

2. Penelitian ini dibatasi pada perusahaan Manufaktur sektor Industri Barang Konsumsi sub sektor Makanan dan Minuman yang terdaftar di Bursa Efek Indonesia.

3. Masa periode pengamatan tahun $2013-2017$.

\section{Hipotesis}

Berdasarkan rumusan masalah yang telah diuraikan sebelumnya, maka penulis dapat merumuskan hipotesa sebagai berikut :

$\mathrm{H}_{\mathrm{a} 1}$ : Rasio Likuiditas berpengaruh secara signifikan terhadap Harga Saham

$\mathrm{H}_{\mathrm{a} 2}$ : Rasio Aktifitas berpengaruh secara signifikan terhadap Harga Saham

$\mathrm{H}_{\mathrm{a} 3}$ : Rasio Solvabilitas berpengaruh secara signifikan terhadap Harga Saham

$\mathrm{H}_{\mathrm{a} 4}$ : Rasio Profitabilitas berpengaruh secara signifikan terhadap Harga Saham

$\mathrm{H}_{\mathrm{a} 5}$ : Pertumbuhan Perusahaan berpengaruh secara signifikan terhadap Harga Saham

$\mathrm{H}_{\mathrm{a} 6} \quad$ : Rasio Likuiditas, Rasio Aktifitas, Rasio Solvabilitas, Rasio Profitabilitas dan Pertumbuhan Perusahaan berpengaruh secara signifikan terhadap Harga

Saham

\section{Kerangka Berpikir}

Menyusun kerangka pemikiran berarti menjawab secara rasional, masalah yang telah disusun dan diidentifikasi (mengapa fenomena itu terjadi) dengan mengalirkan pikiran dari pangkal pikir (premis) berdasarkan patokan pikir sampai pada pemikiran menurut kerangka logis (logical construct).

Teori penunjang dari buku, referensi dari internet serta jurnal riset yang dapat dijadikan referensi dalam penelitian ini. Dari berbagai fenomena teoritis (berdasarkan buku) dan fenomena situasional (berdasarkan kenyataan yang sedang terjadi) akan menimbulkan identifikasi masalah, premis, serta hipotesis, untuk mendapatkan data yang dibutuhkan dilakukan penganalisaan informasi keuangan serta membaca teori yang berkaitan dengan penelitian.

Fenomena situasional dalam penelitian ini yaitu harga saham yang selalu berubah disetiap saat, faktor eksternal dan internal perusahaan dapat memberikan efek yang sangat signifikan dalam perubahan harga saham tersebut, sedangkan perubahan harga tersebut akan memberikan efek seperti keuntungan ataupun kerugian bagi para pemegang saham.

Fenomena teoritis dalam penelitian ini, yaitu variabel Rasio Likuiditas, Rasio Aktifitas, Rasio Solvabilitas, Rasio Profitabilitas dan Pertumbuhan Perushaan sangat dibutuhkan bagi para investor yang akan melakukan investasi di pasar modal karena akan mengetahui sejauh mana investasi yang akan dilakukan investor di suatu perusahaan mampu memberikan return yang sesuai dengan tingkat yang diisyaratkan.

Pengambilan sampel dilakukan dengan mengumpulan data informasi keuangan pada Perusahaan Manufaktur sektor Industri Barang Konsumsi sub sektor Makanan dan Minuman yang telah terdaftar di Bursa Efek Indonesia periode 2013 - 2017.

Variabel yang digunakan dalam penelitian ini, yaitu Rasio Likuiditas $\left(\mathrm{X}_{1}\right)$, Rasio Aktifitas $\left(\mathrm{X}_{2}\right)$, Rasio Solvabilitas $\left(\mathrm{X}_{3}\right)$, Rasio Profitabilitas $\left(\mathrm{X}_{4}\right)$ dan

* Corresponding author's e-mail: ekhatyo11@gmail.com 
Jurnal Ilmiah Akuntansi Universitas Pamulang - Vol. 7, No. 2, Juli 2019 - Marito \& Prasetya

Pertumbuhan Perusahaan $\left(\mathrm{X}_{5}\right)$ sebagai variabel bebas (Independent) terhadap Harga Saham (Y) sebagai variabel terikat (Dependent).

\section{LANDASAN TEORI}

Harga Saham adalah harga dari suatu saham yang ditentukan pada saat pasar saham sedang berlangsung dengan berdasarkan kepada permintaan dan penawaran pada saham yang dimaksud. Harga saham terbentuk dari proses permintaan dan penawaran yang terjadi di bursa. Naik turunnya harga saham yang diperdagangkan di lantai bursa ditentukan oleh kekuatan pasar. "Dalam penilaian saham dikenal adanya tiga jenis nilai yaitu: nilai buku, nilai pasar dan nilai instrinsik saham" (Tandelilin, 2010). Apabila di pasar modal maka penilaian harga saham tergolong dalam nilai pasarnya yang jika pasar bursa tutup, harga yang dimaksud ialah closing pricenya.

Sementara saham sendiri adalah suatu kepemilikan aset seperti instrumen dari kegiatan finansial suatu perusahaan yang biasa disebut juga dengan efek. Harga saham dari suatu perusahaan tentu saja berbeda-beda tergantung bagaimana suatu perusahaan tersebut nilai jualnya di bursa saham. Bagi para investor, tingkat return ini menjadi faktor utama karena return adalah hasil yang diperoleh dari suatu investasi (Jogiyanto, 2000:155)

Dalam dunia saham telah diketahui dua faktor yang sedikitnya mempengaruhi harga saham. Yaitu faktor internal dan eksternal. 1) Faktor internal harga saham : Faktor ini biasanya dipengaruhi dari si penjual atau kemampuan dari suatu perusahaan tersebut dalam menangani kinerja perusahaan baik ekonomi dan manajemen finansialnya. Bagaimana perusahaan tersebut bisa memanage modal yang ada, mengatur kegiatan dari operasional perusahaan tersebut, bagaimana perusahaan tersebut bisa menarik keuntungan dari operasionalnya. 2) Faktor eksternal harga saham : Faktor eksternal biasanya dikaitkan dengan kondisi ekonomi yang terjadi di suatu negara. Misalkan di Indonesia, harga saham bisa saja dipengaruhi oleh kondisi kurs rupiah dan inflasi yang terjadi saat ini atau bulan ini. Huru hara yang terjadi di suatu negara juga kerap dapat mempengaruhi harga saham. Faktor internal yang akan diteliti dalam penelitian ini adalah rasio likuditas, rasio aktifitas, rasio solvabilitas, rasio probabilitas dan pertumbuhan perusahaan.

\section{METODE PENELITIAN}

Pada penelitian ini menggunakan data sekunder, yaitu data yang berupa laporan keuangan dari perusahaan dan website (internet). Teknik pengumpulan data pada penelitian ini adalah dengan metode dokumentasi, yaitu dengan mengumpulkan data yang diperlukan dari berbagai sumber

\section{Operasionalisasi Variabel}

1. Rasio Likuiditas

* Corresponding author's e-mail: ekhatyo11@gmail.com 
Jurnal Ilmiah Akuntansi Universitas Pamulang - Vol. 7, No. 2, Juli 2019 - Marito \& Prasetya

Rasio likuiditas digunakan untuk mengukur kemampuan perusahaan untuk memenuhi liabilitas jangka pendeknya. Salah satu rasio likuiditas yang paling umum dan sering digunakan adalah rasio lancar.

Menurut James C. Van Horne dan John M. Wachowicz (2013 : 168), Current Ratio dapat dihitung dengan cara :

$$
\text { Current Ratio }=\frac{\text { Current Asset }}{\text { Current Liabilitites }}
$$

Sumber : James C. Van Horne dan John M. Wachowicz (2013 : 168)

2. Rasio Aktifitas

Rasio aktivitas juga disebut sebagai rasio efisiensi atau perputaran, mengukur seberapa efektif perusahaan menggunakan berbagai asetnya. Perputaran Persediaan merupakan rasio yang digunakan untuk mengukur berapa kali dana yang ditanam dalam persediaan (inventory) ini berputar dalam satu periode.

Menurut J Fred Weston dalam Kasmir (2012 : 180), Perputaran Persediaan dapat dihitung dengan cara

$$
\text { Inventory Turnover }=\frac{\text { Sales }}{\text { Inventory }}
$$

3. Rasio Solvabilitas (Leverage)

Untuk dapat menguji sejauh mana perusahaan menggunakan uang yang dipinjam dapat menggunakan rasio hutang (Leverage).

Menurut James C. Van Horne dan John M. Wachowicz (2013 : 168), Rasio Leverage dapat dihitung dengan cara :

4. Rasio Profitabilitas

$$
\text { Leverage Ratio }=\frac{\text { Total Debt }}{\text { Total Equity }}
$$

Rasio Profitabilitas terdiri atas dua jenis rasio yang menunjukkan profitabilitas dalam kaitannya dengan penjualan dan rasio yang menunjukkan profitabilitas dalam kaitannya dengan investasi. Net Profit Margin adalah ukuran profitabilitas perusahaan dari penjualan setelah memperhitungkan semua biaya dan pajak penghasilan

Menurut James C. Van Horne dan John M. Wachowicz hasil alih bahasa Quratul Ain Mubarakah (2013 : 181), Net Profit Margin dapat dihitung dengan cara :

$$
\text { Net Profit Margin }=\frac{\text { Laba Bersih Setelah Pajak }}{\text { Penjualan Bersih }}
$$

Sumber : James C. Van Horne dan John M. Wachowicz hasil alih bahasa Quratul Ain Mubarakah (2013 : 181)

5. Pertumbuhan Perusahaan

Menurut Yeniatie dan Destriana (2010), "Pertumbuhan perusahaan adalah tingkat perubahan laba dari tahun ke tahun".

Pertumbuhan Perusahaan dapat diukur dengan rumus :

* Corresponding author's e-mail: ekhatyo11@gmail.com 
Jurnal Ilmiah Akuntansi Universitas Pamulang - Vol. 7, No. 2, Juli 2019 - Marito \& Prasetya

$$
\text { Growth }=\frac{\text { Laba Tahun Berjalan }- \text { Laba Tahun Sebelumnya }}{\text { Laba Tahun Sebelumnya }}
$$

Sumber : Yeniatie dan Destriana (2010)

6. Harga Saham

Harga saham adalah nilai nominal penutupan (clossing price) dari penyertaan atau pemilikan seseorang atau badan dalam suatu perusahaan atau perseroan terbatas yang berlaku secara reguler di pasar modal di Indonesia. Kesuma (2009).

Harga Saham didefinisikan sebagai, "The last reported sales price for an exchange traded security”. Dalton (1993 : 267) dalam Rahmandia (2013).

Harga saham penutupan (closing price) adalah harga yang dimiliki oleh penjual dan pembeli pada saat akhir hari sehingga inilah yang menyatakan naik turunnya suatu saham, selain itu harga penutupan tidak akan lagi berubah pada periode waktu tersebut (hari) karena pasar telah ditutup, sehingga harga saham penutupan ini dipandang layak untuk mewakili pencerminan harga suatu saham pada periode tertentu.

\section{Obyek Penelitian}

Tabel 1

Sampel Penelitian

\begin{tabular}{|c|l|c|}
\hline No & \multicolumn{1}{|c|}{ Kriteria } & Jumlah \\
\hline 1 & $\begin{array}{l}\text { Perusahaan Maufaktur sektor Industri Barang Konsumsi } \\
\text { subsektor Makanan dan Minuman yang terdaftar di BEI } \\
\text { periode 2013 - 2017 }\end{array}$ & $\begin{array}{c}\text { (7) } \\
\text { Perusahaan yang tidak memiliki laporan keuangan lengkap / } \\
\text { rugi selama periode 2013 - 2017 }\end{array}$ \\
\hline & Jumlah perusahaan yang tersedia untuk dijadikan sampel & $\mathbf{1 1}$ \\
\hline
\end{tabular}

Sumber : Website BEI yang diolah kembali

\section{HASIL DAN PEMBAHASAN}

Tabel 2

Uji Hipotesa

Model Summary ${ }^{b}$

\begin{tabular}{|l|c|r|r|c|}
\hline Model & $\mathrm{R}$ & $\mathrm{R}$ Square & $\begin{array}{c}\text { Adjusted R } \\
\text { Square }\end{array}$ & $\begin{array}{c}\text { Std. Error of } \\
\text { the Estimate }\end{array}$ \\
\hline 1 &, $820^{\mathrm{a}}$ &, 672 &, 639 & 148979,298 \\
\hline
\end{tabular}

a. Predictors: (Constant), GROWTH, PROFITABILITAS, ACTIVITY

RATIO, SOLVABILITAS, LIKUIDITAS

b. Dependent Variable: HARGA SAHAM

* Corresponding author's e-mail: ekhatyol1@gmail.com 
Jurnal Ilmiah Akuntansi Universitas Pamulang - Vol. 7, No. 2, Juli 2019 - Marito \& Prasetya

\begin{tabular}{|c|c|c|c|c|c|c|c|c|}
\hline \multicolumn{9}{|c|}{ Coefficients $^{a}$} \\
\hline \multirow{2}{*}{\multicolumn{2}{|c|}{ Model }} & \multicolumn{2}{|c|}{ Unstandardized Coefficients } & \multirow{2}{*}{$\begin{array}{c}\text { Standardized } \\
\text { Coefficients }\end{array}$} & \multirow[b]{2}{*}{$\mathrm{t}$} & \multirow[b]{2}{*}{ Sig. } & \multicolumn{2}{|c|}{ Collinearity Statistics } \\
\hline & & $B$ & Std. Error & & & & Tolerance & VIF \\
\hline \multirow[t]{6}{*}{1} & (Constant) & $-108785,791$ & 58118,582 & & $-1,872$ &, 067 & & \\
\hline & LIKUIDITAS & $-25676,013$ & 18927,815 &,- 170 & $-1,357$ & 181 & .422 & 2,371 \\
\hline & ACTIVITY RATIO & $-2054,818$ & 1778,604 &,- 098 & $-1,155$ &, 254 &, 923 & 1,083 \\
\hline & SOLVABILITAS & 121609,014 & 24669,365 &, 536 & 4,930 &, 000 &, 560 & 1,787 \\
\hline & PROFITABILITAS & 1330160,927 & 284962,465 &, 530 & 4,668 &, 000 &, 514 & 1,947 \\
\hline & GROWTH & $-38039,141$ & 29104,184 &,- 108 & $-1,307$ & 197 & 963 & 1,038 \\
\hline
\end{tabular}

a. Dependent Variable: HARGA SAHAM

ANOVA ${ }^{a}$

\begin{tabular}{|ll|l|r|r|r|c|}
\hline \multicolumn{2}{|c|}{} & \multicolumn{1}{|c|}{$\begin{array}{l}\text { Sum of } \\
\text { Squares }\end{array}$} & $\mathrm{df}$ & Mean Square & $\mathrm{F}$ & Sig. \\
\hline 1 & Regression & $2,231 \mathrm{E}+12$ & 5 & $4,462 \mathrm{E}+11$ & 20,103 &, $000^{\mathrm{b}}$ \\
& Residual & $1,088 \mathrm{E}+12$ & 49 & $2,219 \mathrm{E}+10$ & & \\
& Total & $3,318 \mathrm{E}+12$ & 54 & & & \\
\hline
\end{tabular}

a. Dependent Variable: HARGA SAHAM

b. Predictors: (Constant), GROWTH, PROFITABILITAS, ACTIVITY RATIO, SOLVABILITAS, LIKUIDITAS

Sumber : Output Software SPSS

1. Koefisien Determinasi

Berdasarkan hasil output Uji Hipotesa, dapat dilihat nilai Adjusted $R$ Square sebesar 0,639. Hal ini berarti 63,9\% variabel Harga Saham dapat dijelaskan oleh variabel Independen yang diteliti, yaitu Rasio Likuiditas, Rasio Aktifitas, Rasio Solvabilitas, Rasio Profitabilitas dan Pertumbuhan Perusahaan. Sedangkan sisanya sebesar 36,1\% dijelaskan oleh variabel / faktor lain di luar model (tidak diteliti).

2. Uji T (Parsial)

Berdasarkan hasil output Uji Hipotesa, dapat dilihat nilai Probabilitas signifikansi masing - masing variabel adalah :

1) Rasio Likuiditas (X1) sebesar $0,181>0,05$, maka Hal ditolak yang berarti Rasio Likuiditas tidak berpengaruh signifikan terhadap Harga Saham.

2) Rasio Aktifitas (X2) sebesar 0,254 >0,05, maka Ha2 ditolak yang berarti Rasio Aktifitas tidak berpengaruh signifikan terhadap Harga Saham.

3) Rasio Solvabilitas (X3) sebesar $0,000<0,05$, maka Ha3 diterima yang berarti Rasio Solvabilitas berpengaruh signifikan terhadap Harga Saham.

4) Rasio Profitabilitas (X4) sebesar 0,000 < 0,05, maka Ha4 diterima yang berarti Rasio Profitabilitas berpengaruh signifikan terhadap Harga Saham

5) Pertumbuhan Perusahaan (X5) sebesar 0,197 > 0,05, maka Ha5 ditolak yang berarti Pertumbuhan Perusahaan tidak berpengaruh signifikan terhadap Harga Saham.

3. Uji F (Simultan)

Berdasarkan hasil output Uji Hipotesa, dapat dilihat nilai Prob (F Statistik) sebesar $0,00<0,05$, maka Ha6 diterima yang berarti Rasio Likuiditas, Rasio Aktifitas, Rasio Solvabilitas, Rasio Profitabilitas dan 
Jurnal Ilmiah Akuntansi Universitas Pamulang - Vol. 7, No. 2, Juli 2019 - Marito \& Prasetya

Pertumbuhan Perusahaan secara simultan (bersama - sama) berpengaruh signifikan terhadap Harga Saham.

\section{PENUTUP}

\section{Kesimpulan}

Penelitian ini menggunakan alat pengujian analisis linear berganda. Hasil penelitian ini merupakan hasil pengolahan data menggunakan software SPSS. Setelah dilakukan penelitian diperoleh kesimpulan sebagai berikut :

1. Variabel Rasio Likuiditas secara parsial tidak berpengaruh signifikan terhadap variabel Harga Saham.

2. Variabel Rasio Aktifitas secara parsial tidak berpengaruh signifikan terhadap variabel Harga Saham.

3. Variabel Solvabilitas secara parsial berpengaruh signifikan terhadap variabel Harga Saham.

4. Variabel Profitabilitas secara parsial berpengaruh signifikan terhadap variabel Harga Saham.

5. Variabel Pertumbuhan Perusahaan secara parsial tidak berpengaruh signifikan terhadap variabel Harga Saham.

6. Variabel Rasio Likuiditas, Rasio Aktifitas, Rasio Solvabilitas, Rasio Profitabilitas dan Pertumbuhan Perusahaan secara simultan berpengaruh signifikan terhadap variabel Harga Saham.

\section{Saran}

1. Penelitian Berikutnya

1) Bagi penelitian berikutnya yang akan melakukan penelitian dengan topik sejenis disarankan hendaknya untuk menambahkan variabel lain yang belum dimasukan ke dalam penelitian ini. Contohnya : Price Book Value, Return On Equity, Market Value Added, Devidend Per Share, Tingkat Inflasi, Kurs, Suku Bunga dan lain - lain.

2) Dalam melakukan penelitian ini, hendaknya peneliti lebih memahami terlebih dahulu mengenai variabel - variabel yang berkaitan dengan instrumen penelitian tersebut.

3) Penelitian mendatang hendaknya memperbanyak perusahaan yang menjadi sampel penelitian, baik dari jenis perusahaan maupun dari sektor perusahaan sehingga sampel yang digunakan dapat mewakili semua karakteristik dalam populasi dan dapat mencerminkan kenyataan yang sesungguhnya.

4) Periode pengamatan pada penelitian hendaknya lebih diperpanjang, sehingga hasil penelitian mencerminkan fenomena yang sesungguhnya dan hasil penelitian akan lebih baik.

2. Pembaca dan Investor

1) Bagi pembaca, penelitian ini diharapkan dapat memberikan pengetahuan khususnya mengenai pengaruh Rasio Likuiditas, Rasio Aktifitas, Rasio

* Corresponding author's e-mail: ekhatyo11@gmail.com 
Jurnal Ilmiah Akuntansi Universitas Pamulang - Vol. 7, No. 2, Juli 2019 - Marito \& Prasetya

Solvabilitas, Rasio Profitabilitas dan Pertumbuhan Perusahaan terhadap Harga Saham.

2) Bagi investor diharapkan menilai kinerja menggunakan metode lain yang mungkin lebih relevan. Peneliti juga menyarankan kepada Investor untuk selalu berhati - hati dalam menanamkan modal karena tidak semua perusahaan yang dianggap prospektif dapat menghasilkan nilai tambah yang tinggi.

\section{DAFTAR PUSTAKA}

Ghozali, I. dan Ratmono D. (2013). Analisis Multivariat dan Ekonometrika : Teori, Konsep dan Aplikasi dengan Eviews 8. Semarang : Universitas Diponogoro.

Gitman J. Lawrence \& Chad J Zutter. (2012). Principle of Managerial Finance. England: Pearson.

Horne, JCV. dan Wachowicz JM. (2013). Prinsip Manajemen Keuangan. Jakarta : Salemba Empat.

Husnan, Suad. (2009). Dasar-Dasar Teori Portofolio dan Analisis Sekuritas. Edisi Keempat. Yogyakarta : UPP STIM YKPN.

Indriantoro, N. dan Supomo B. (2014). Metodologi Penelitian Bisnis untuk Akuntansi dan Manajemen. Edisi Pertama. Yogyakarta : BPFE.

Priyatno, D. 2012. Cara Kilat Belajar Analisis Data dengan SPSS 20. Yogyakarta : CV Andi Offset.

Rodoni, A. dan Ali H. (2014). Manajemen Keuangan Modern. Jakarta : Mitra Wacana Media.

Syamsuddin, L. (2007). Manajemen Keuangan Perusahaan : Konsep Aplikasi dalam Perencanaan, Pengawasan dan Pengambilan Keputusan. Jakarta : PT Raja Grafindo Persada.

Tandelilin, Eduardus. (2010). Portofolio dan Investasi. Edisi Pertama. Yogyakarta: Kanisius

Jogiyanto. (2000). Teori Portofolio dan Analisis Investasi. Edisi 3. BPFE, Yogyakarta. 